\title{
The Relationships Between School Principals' Suitability and School Culture in Relation to Teacher Performance
}

\author{
Bintang R. Simbolon, Erni Murniarti*, Rinto Situmorang \\ Educational Management of Postgraduate Program,Universitas Kristen Indonesia \\ erni.murniarti@uki.ac.id
}

\begin{abstract}
This study employed quantitative research that is descriptive-analytic, quantitative in the sense that this study conducted statistical tests to measure how much the relationship or strength of the relationship between the variables studied. The results of the study are as follows: 1). Relationship between Principal Competence and Teacher Performance Improvement, where the t value of 2.224 with Sig. $(\mathrm{p}=0.033)<0.05$. 2). The relationship between school culture and teacher performance improvement, where t value is 2.642 with Sig. $(\mathrm{p}=0.014)<0.05$. 3). The Sig also shows it. $\mathrm{F}(\mathrm{p}=0,000)$ or $\mathrm{p}<0.05$. Based on these results, it is concluded that there is a positive relationship between principal competence and school culture and teacher performance improvement.
\end{abstract}

Keywords: Principal Competence, School Culture, Teacher Performance

\section{INTRODUCTION}

In carrying out various tasks and jobs, teachers often do different interactions in their work environment, either with students or fellow professionals (Range, 2012). Teachers' obligations and roles will be increasingly complex, with the development in the field of science and technology are pretty rapid today. Therefore, teachers must continually develop and improve their skills to properly carry out their teaching duties (Abdullah, 2019). Competence is the knowledge, expertise and ability that a person has/achieves that is a part of him to carry out the appearance of specific cognitions, affections, and psychomotor behaviors (Ayundasari, 2017).

\section{LITERATURE REVIEW Teacher Performance}

Performance is a universal concept that is the organization's operational efficiency, part of the organization, and its employees based on predetermined standards and criteria (Hendrawijaya \& Indrianti, 2020). Performance is a fundamental behavior that everyone displays as a work achievement generated by employees under their company's role (Fardah, 2012). Employee performance is crucial in the company's efforts to achieve its goals (Aziizah, 2018).

Teacher performance has certain specifications (Syamsyuddin, 2020). It can be seen and measured based on the specifications or competency criteria that must be owned by each teacher (Suriansyah, 2014). A form of teacher behavior that describes its performance is a teacher's activity in the learning process, namely how a teacher plans learning, carrying out teaching activities, and assess learning outcomes (Winaryo, 2016). Conceptually and generally, the performance of teachers achieves the task of competency aspects, namely professional competence, social competence, and personal competence (Kartini \& Fitria, 2020)

\section{Factors Affecting Teacher Performance}

The factors that influence performance into 3 (three) groups, namely individual competence, organizational support, and management support. According to Mc Ashan, "Competency is 
acknowledged, skills, and abilities or capabilities that a person achieves, which becomes part of his or her being to the extent he or she can satisfactorily perform particular cognitive, affective, and psychomotor behaviors" (Kristiawan \& Lestari, 2017). Competence could described as a behavior or behavior that represents a good performance from a work context. (Komar, 2020). Education leaders/principals have three leading roles: the key to shaping school culture, leaders, and curriculum makers (Kusumaningtyas \& Setyawati, 2015). Duties and Responsibilities of the Principal (Eger, 2020).

\section{School Culture}

Culture is not only because it is agreed and embraced, but because it has strength, it is not easily changed (Mangkunegara \& Prabu, 2004). Organizational culture can influence the organization's overall activities and direct each member of its behavior towards the achievement. Corporate culture contains a combination of values, beliefs, traditions, assumptions, perceptions, norms, peculiarities, and patterns of behavior. Managerial culture functions among others as an identity giver, an adhesive of commitment, improvement of social system stability and behavioral influence (Lewis \& King,
2016). School culture is a relatively decisive and consistently predictive factor among the many factors influencing how teachers are happy with their jobs (Kristiawan, 2019). School culture is a unique asset and is not the same as one school (Muniarti \& Zebua, 2016).

\section{METHODS}

This research is correlational research using quantitative methods and data collection techniques using questionnaires. This research was conducted in the even semester of 2019/2020 at SD Kasih Immanuel North Jakarta from July 2019 to December 2019. The population in this study was 30 teachers at SD Kasih Immanuel. In the concept of population, know two types: the idea of the target population and the affordable population. The target population is the comprehensive human resources (Teachers, TU staff, security guards) at SD Kasih Immanuel. The reasonable population is the entirety of SD Kasih Immanuel Teachers in the 2019/2020 school year. While the samples studied are all the works in SD Kasih Immanuel and the proportional random sampling method used in this research.

\section{RESULTS AND DISCUSSION}

Table 1

Multiple Linear Regression Analysis Results Table

Coefficients

\begin{tabular}{|c|c|c|c|c|c|c|}
\hline & \multirow[b]{2}{*}{ Model } & \multicolumn{2}{|c|}{ Unstandardized Coefficients } & \multirow{2}{*}{$\begin{array}{c}\begin{array}{r}\text { Standardized } \\
\text { Coefficients }\end{array} \\
\text { Beta }\end{array}$} & \multirow[b]{2}{*}{ t } & \multirow[b]{2}{*}{ Sig } \\
\hline & & B & $\begin{array}{l}\text { Std. } \\
\text { Error }\end{array}$ & & & \\
\hline \multirow[t]{2}{*}{1} & (Constant) & 25.417 & $\begin{array}{l}11.76 \\
3 \\
164\end{array}$ & 380 & 2.161 & .040 \\
\hline & $\begin{array}{l}\text { School } \\
\text { Culture }\end{array}$ & .401 & .152 & .458 & 2.642 & .014 \\
\hline
\end{tabular}




\section{Hypothesis Test}

Obtained t value of 2,242 with Sig value. $(\mathrm{p}=0.033)<0.05$, so it can be concluded that Ho was rejected. This means that in part, the Principal Competency variable (X1) has a significantly positive effect on Teacher Work
(Y). Thus, the first hypothesis proposed earlier is acceptable.

Decision-making done using two ways: First, the F-test (F-test) test can be done by comparing F count with Ftable. The test criteria are if Fcalculate $>\mathrm{F}$ table table then Ho isrejected and Hais accepted, while if Fcalculates < F tabletabel then Hois accepted and Ha isrejected. Second, using a value of significance,

Table 2

Simultaneous Test Result (Test F)

ANOVA

\begin{tabular}{|ll|l|l|l|l|r|}
\hline Model & & Sum of Squares & \multicolumn{1}{|c|}{ df } & Mean Square & F & Sig. \\
\hline 1 & Regression & 2474.139 & 2 & 1237.070 & 21.972 & $.000^{\mathrm{a}}$ \\
& Residual & 1520.161 & 27 & 56.302 & & \\
& Total & 3994.300 & 29 & & & \\
\hline
\end{tabular}

a. Predictors: (Constant), School Culture, Principal Competence

b. Dependent Variable: Teacher's Work

From the results of the analysis in Table 2 above, it can seem that the value of probability (Sig.) $=0.000(\mathrm{p}=0.000)$ or $\mathrm{p}<0.05$, so it can be concluded that Ho (Principal Competency Variable and School Culture simultaneously does not affect Teacher's Work) rejected. This means that the principal's competence variables and school culture jointly affect the teacher's
work(Y). Thus, the third hypothesis proposed earlier is acceptable.

\section{Coefficient of Determination}

The result of the calculation of the coefficient of judgment can be presented in Table 3:

Table 3

Coefficient's Value

Model Summary ${ }^{b}$

\begin{tabular}{|l|r|l|l|c|}
\hline Model & $\mathrm{R}$ & $\mathrm{R}$ Square & Adjusted R Square & $\begin{array}{c}\text { Std. The error of } \\
\text { the Estimate }\end{array}$ \\
\hline 1 & $.787^{\mathrm{a}}$ & .619 & .591 & 7.50348 \\
\hline
\end{tabular}

The calculation of Table 6 indicates that the value of $R 2$ is obtained by 0.619 . This means that the influence of the Principal's Competence with School Culture for Teacher Work is $61.9 \%$.

The amount of influence of each free variable can be known from the multiplication between the standard coefficient (beta) and the zero-order correlation (product-moment correlation) as follows: 
Table 4

Variable Influence

\begin{tabular}{|l|l|c|c|}
\hline \multicolumn{1}{|c|}{ Variable } & $\begin{array}{l}\text { Beta } \\
\text { coefficient }\end{array}$ & $\begin{array}{c}\text { Zero-order } \\
\text { correlation }\end{array}$ & $\begin{array}{c}\text { Great } \\
\text { Influence }\end{array}$ \\
\hline Principal Competence & 0.389 & 0.722 & 0.280 \\
\hline School Culture & 0.458 & 0.741 & 0.339 \\
\hline & & Total & 0.619 \\
\hline
\end{tabular}

Table 4 above, known, the significant influence of all free variables is $0.619 \%$. The value consists of the contribution of the Principal Competency variable of 0.280 or $28.0 \%$ and school culture of 0.339 or $33.9 \%$.

\section{The Relationship of The Principal's Competence with Teacher Performance}

From the results of regression analysis, obtained $\mathrm{t}$ value of 2,242 with $\mathrm{Sig}$ value. $(\mathrm{p}=0.033)<0.05$, so it can be concluded that Ho was rejected. This means that in part, the Principal Competency variable (X1) has a significantly positive effect on Teacher Performance (Y). Thus, the first hypothesis proposed earlier is acceptable (Robbins \& Judge, 2015).

The correlation between the principal's competence and performance shows its meaning, either through product-moment correlation or partial correlationc. This analysis showed that the headmaster's competence is one of the main factors contributing to teacher performance.

\section{The school's cultural relationship with teacher performance}

The results found that school culture has a relationship with performance. This was justified based on the results of regression analysis obtained $t$ value of 2,642 with $\mathrm{Sig}$ value. $(\mathrm{p}=0.014)<0.05$, so it can be concluded that Ho was rejected. This means that, in part, the School Culture variable (X1) significantly positive effect on Teacher Performance (Y). Thus, the first hypothesis proposed earlier is acceptable (Rifma, 2018).
Performance is an activity carried out to carry out, complete tasks and responsibilities under the expectations and objectives set. This is under research conducted by Winaryo (2018) showing that the influence of the headmaster's managerial competence and school culture on the school's effectiveness was obtained by 0.403 or $40.3 \%$ with a positive regression coefficient. It is appropriate based on the results of the analysis, the value of Sig. $F(p=0.000)$ or $p<0.05$, so it can be concluded that Ho was rejected. This means that the principal's competence variables and school culture are jointly towards teacher performance (Y). Thus, the third hypothesis proposed earlier is acceptable.

\section{CONCLUSIONS AND SUGGESTIONS Conclusions}

The analysis results can be concluded several things as follows: 1) There is a positive and significant relationship between the headmaster's competence to teacher performance, which is indicated by a grade of 2,242 and a Sig score. $(\mathrm{p}=0.033)<0.05$, which means there is a significant relationship between the headmaster's competence to teacher performance at SD Kasih Immanuel North Jakarta; 2)There is a positive and significant relationship between school culture and teacher performance, which is shown by at grade of 2,642 and a Sig score. $(\mathrm{p}=0.014)<$ 0.05 , which means there is a significant connection between school culture and teacher performance at SD Kasih Immanuel, North Jakarta; 3)There is a positive and significant relationship between the headmaster's competence and the school culture together with the teacher's performance, and Sig pointed out. $(\mathrm{p}=0.000)$ or $\mathrm{p}<0.05$, which means there is a 
significant connection between the headmaster's leadership style and school culture to teachers' performance at SD Kasih Immanuel North Jakarta. Thus, this research's hypothesis was accepted that there is a positive relationship between the competence of the principal and the culture of the school to the performance of teachers of SD Kasih Immanuel, North Jakarta.

\section{REFERENCES}

1. Abdullah, M. (2019). School culture to serve performance of Madrasah in Indonesia. QIJIS: Qudus International Journal of Islamic Studies, 7(1), 71-100.

2. Ayundasari, D. Y., Sudiro, A., \& Irawanto, D. W. (2017). They are improving employee performance through work motivation and self-efficacy mediated by job satisfaction. Jurnal Aplikasi Manajemen, 15(4), 587-599.

3. Aziizah, D. R., Wirawan, W., \& Thalib, S. (2018). Pengaruh Gaya Kepemimpinan Kepala Sekolah Dan Budaya Organisasi Terhadap Kinerja Guru Dengan Kepuasan Kerja Sebagai Variable Intervening. Jurnal Ilmiah Ekbank, 1(2).

4. Eger, L., \& Prášilová, M. (2020). The Relation between School Culture SubCategories and Expected Results of Learning Process. Problems of Education in the 21st Century, 78(1), 48-60.

5. Fardah, K. (2012). Hubungan Persepsi Guru Tentang Kepemimpinan Kepala Sekolah Dan Budaya Organisasi Dengan Kinerja Guru Madrasah Tsanawiyah Negeri Kabupaten Deli Serdang (Doctoral dissertation, UNIMED).

6. Hendrawijaya, A. T., Hilmi, M. I., Hasan, F., Imsiyah, N., \& Indrianti, D. T. (2020). Determinants of Teacher Performance with Job Satisfactions Mediation. International Journal of Instruction, 13(3), 845-860.

7. Kartini, D., Kristiawan, M., \& Fitria, H. (2020). The Influence of Principal's Leadership, Academic Supervision, and Professional Competence toward Teachers' Performance. International Journal of Progressive Sciences and
Technologies, 20(1), 156-164.

8. Komar, A. (2020). Peningkatan Kinerja Guru Berbasis Budaya Sekolah dan Motivasi Kerja Guru. At-Ta'lim: Jurnal Pendidikan, 6(2), 109-117.

9. Kusumaningtyas, A., \& Setyawati, E. (2015). Teacher Performance of the State Vocational High School Teachers in Surabaya. International Journal of Evaluation and Research in Education, 4(2), 76-83.

10. Lewis, J., Asberry, J., DeJarnett, G., \& King, G. (2016). The Best Practices for Shaping School Culture for Instructional Leaders. Alabama Journal of Educational Leadership, 3, 57-63.

11. Mangkunegara, A. P., \& Prabu, A. (s2004). Manajemen Sumber Daya Manusia, Cetakan Pertama. Bandung: PT. Remaja Rsodakarya.

12. Murniarti, E., \& Zebua, A. P. (2016). Hubungan Kompensasi dan Budaya Organisasi Dengen Komitmen Organisasi Guru di Yayasan Pendidikan Eka Wijaya Bogor.

13. Rifma, R., Rusdinal, R., \& Meizatri, R. (2018). Vocational High School Culture. Journal of Educational and Learning Studies, 1(1), 23-28.

14. Robbins, S. P., \& Judge, T. A. (2015). Organization Behaviour. Jakarta: Salemba Empat.

15. Suriansyah, A. (2014). Hubungan budaya sekolah, komunikasi, dan komitmen kerja terhadap kinerja guru sekolah dasar negeri. Jurnal Cakrawala Pendidikan, 33(3).

16. Syamsuddin, S. (2020). Kepemimpinan Kepala Sekolah dan Pengembangan Budaya di Sekolah. Al Asma: Journal of Islamic Education, 2(1), 81-96.

17. Winaryo, W., Miyono, N., \& Retnaningdyastuti, R. (2016). Pengaruh Kompetensi Manajerial Kepala Sekolah Dan Budaya Sekolah Terhadap Efektivitas Sekolah Di Kabupaten Pemalang. Jurnal Manajemen Pendidikan (JMP), 5(3) 